\title{
Monitoring of Bone Resorption after Renal Transplantation by Measuring the Urinary Excretion of Pyridinium Cross-Links
}

\author{
By W. Withold ${ }^{1}, S$. Degenhardt ${ }^{2}$, M. Heins ${ }^{1}$, B. Grabensee ${ }^{2}$ and H. Reinauer ${ }^{1}$ \\ 1 Institut für Klinische Chemie und Laboratoriumsdiagnostik \\ 1 Klinik für Nephrologie \\ Medizinische Einrichtungen der Heinrich-Heine-Universität Düsseldorf, Düsseldorf, Germany
}

(Received February 16/September 5, 1994)

Summary: The urinary excretion of pyridinium cross-links was measured in 70 second morning urine samples from 49 patients following renal transplantation.

One and three months after renal transplantation, the urinary excretion of pyridinium cross-links was higher $(p<0.05)$ than at one week after transplantation. At all times after transplantation, the values for the excretion of pyridinium cross-links were correlated with the bone alkaline phosphatase concentrations $(p<0.001)$. However, there was no correlation between parathyrin concentrations and the values for the excretion of pyridinium crosslinks ( $p>0.05$ ). This rise in the excretion of pyridinium cross-links is probably due to an increase of bone resorption caused by cyclosporin A and/or glucocorticoids.

In the case of 17 urines with excretion values of pyridinium cross-links above the upper reference limit (pyridinoline equivalents, $93 \mu \mathrm{mol} / \mathrm{mol}$ creatinine), only $2(12 \%)$ of the corresponding sera showed increased bone alkaline phosphatase values. In patients following renal transplantation simultaneous assessment of bone formation and bone resorption (determined from bone alkaline phosphatase serum concentrations and the excretion of pyridinium crosslinks) may therefore enhance the diagnostic sensitivity for detecting effects on bone metabolism.

\section{Introduction}

Type I collagen accounts for about $90 \%$ of the organic matrix of mineralized bone. The organic matrix is stabilized by the formation of pyridinium cross-links between the terminal, non-helical part of a type I collagen molecule and the helical region of another. The cross-links found in type I collagen of bone are formed from two hydroxylysine residues and one lysine residue $(=\mathrm{de}-$ oxypyridinoline) or from three hydroxylysine residues (= pyridinoline) (1). When the collagen matrix is degraded, both kinds of cross-links are released into the circulation and excreted in the urine. Deoxypyridinoline is found almost exclusively in bone, whereas pyridinoline is located in the collagen fibrils of bone as well as cartilage (for review see 1.c. (2)). The excretion of pyridinium cross-links in urine is considered to be an index of the activity of bone resorption (e.g. due to primary hyperparathyroidism) (3).

Bone alkaline phosphatase (EC 3.1.3.1) is localized in the plasma membrane of osteoblastic cells and may be considered as a marker of osteoblastic activity and of bone formation (4).

In chronic renal failure secondary hyperparathyroidism ensues from diminished calcitriol production and impaired excretion of inorganic phosphate. This leads to different forms of osteopathy including osteitis fibrosa, osteomalacia and suppressed bone remodeling. Following renal transplantation, the restoration of glomerular filtration does not always completely normalize the structure and function of bone tissue (e.g. hyperparathyroidism may persist due to the increased mass of the parathyroid glands). Additionally, new skeletal de- 
rangements result from the action of the immunosuppressive agents that are used to maintain the allograft (for review see 1.c. (5)).

The present report describes the use of a competitive enzyme immunoassay for determination of the urinary excretion of pyridinium cross-links in the follow-up of patients receiving renal transplants. Excretion values for pyridinium cross-links were compared with bone alkaline phosphatase mass concentrations (as determined immunoradiometrically) as well as with intact parathyrin concentrations in plasma.

Parts of this work have been presented in a preliminary form (6).

\section{Materials and Methods}

\section{Patients}

We examined 90 venous blood specimens (serum as well as plasma; in the latter case the potassium salt of ethylenediaminetetraacetic acid was used as anticoagulant) and 70 second morning urine samples from 49 patients ( 26 males, 23 females; age-range $25-66$ years) who had undergone cadaveric renal transplantation. Samples were obtained between 8.00 and 10.00 a.m.

Cyclosporin A was given i.v. during the first 2 postoperative days at a daily dose of $1 \mathrm{mg} / \mathrm{kg}$ body weight, thereafter in daily oral doses of $5 \mathrm{mg} / \mathrm{kg}$ body weight. The dosage was adapted to achieve a concentration of cyclosporin $A$ in whole blood between 120 and $160 \mu \mathrm{g} / 1$ (for determination of cyclosporin A see below). Azathioprine was given at a daily oral dose of $2 \mathrm{mg} / \mathrm{kg}$ body weight. Methylprednisolone was given during the first 2 postoperative days at a daily dose of $250 \mathrm{mg}$ i.v., during the next 4 days at a daily oral dose of $100 \mathrm{mg}$, followed thereafter by a daily oral dose of $1 \mathrm{mg} /$ $\mathrm{kg}$ body weight, gradually decreasing to $0.1 \mathrm{mg} / \mathrm{kg}$ body weight 2 months after transplantation.

Tables 1 and 2 give further information on the sampling times of serum, plasma and urine.

\section{Determination of urinary excretion of pyridinium "cross-links"}

Urinary excretion of pyridinium cross-links was determined by a competitive enzyme immunoassay (Collagen Crosslinks ${ }^{\mathrm{TM}} \mathrm{Kit}$; Metra Biosystems Inc.; Palo Alto, CA [U. S. A.]; No. 8001; lot No. 3F01) employing a polyclonal antibody against pyridinoline which shows $100 \%$ cross-reactivity with deoxypyridinoline. A calibration curve was constructed by employing a 4-parameter curve fitting equation. Between-assay imprecision was $<10 \%$. Urinary excretion of pyridinium cross-links is given as pyridinoline equivalents in $\mu \mathrm{mol} / \mathrm{mol}$ creatinine.

The following reference interval (2.5th to 97.5 th percentile) for excretion of pyridinium cross-links in second moming urine samples was established in apparently healthy persons (urine samples ples was established in appareen 8.00 and $10.00 \mathrm{a}$. m.): pyridinoline equivalents, $13-93$ (median: 46$) \mu \mathrm{mol} / \mathrm{mol}$ creatinine $(\mathrm{n}=99 ; 51$ males lents, 13-93 (median: 46 and 48 females; range of age: $19-62$ [median: 29] years). There was no dependence of reference values on $\operatorname{sex}(p>0.1)$.

\section{Determination of bone alkaline phosphatase mass concentration in serum}

Bone alkaline phosphatase mass concentration was determined by an immunoradiometric assay (Tandem ${ }^{\circledR}-\mathrm{R}$ Ostase ${ }^{\mathrm{TM}}$; Hybritech Inc., San Diego, CA [U. S. A.]; no. 3040 BE; lot No. 35077 08G) employing two antibodies against two different epitopes of the bone alkaline phosphatase molecule. A calibration curve was constructed by linear interpolation between the plotted analytical results. Between-assay imprecision was $<10 \%$.

The following reference intervals (2.5th-97.5th percentile) for bone alkaline phosphatase mass concentration in serum were established in apparently healthy persons:

(1) $3.8-21.3 \mu \mathrm{g} / \mathrm{l}$ (males, $\mathrm{n}=51$ )

(2) $3.4-15.0 \mu \mathrm{g} / \mathrm{l}$ (females, $\mathrm{n}=51$ ).

The age-ranges were 20-55 years (males) and 18-56 years (females).

Determination of intact parathyrin concentration in plasma

Concentration of intact parathyrin was determined by employing N-tact ${ }^{\circledR}$ PTH (INCSTAR Corporation, Stillwater, Minnesota [U.S. A.]; No. 22800 ) (reference interval: $1.1-5.8 \mathrm{pmol} / \mathrm{l}$ ).

Determination of creatinine concentration in serum and urine

The creatinine concentration in serum and urine was determined with the fully mechanized analyser Hitachi/BM 704 (Boehringer Mannheim GmbH, Mannheim, Germany), employing a kinetic modification of the Jaffé procedure (7).

Tab. 1 Comparison of urinary excretion of pyridinium cross-links at different times after renal transplantation.

\begin{tabular}{llllll}
\hline & \multicolumn{3}{l}{ Time after renal transplantation } & & \\
\cline { 2 - 6 } & $\begin{array}{l}1 \text { week } \\
(\mathrm{n}=26)\end{array}$ & $\begin{array}{l}1 \text { month } \\
(\mathrm{n}=18)\end{array}$ & $\begin{array}{l}3 \text { months } \\
(\mathrm{n}=8)\end{array}$ & $\begin{array}{l}6 \text { months } \\
(\mathrm{n}=7)\end{array}$ & $\begin{array}{l}12 \text { months } \\
(\mathrm{n}=11)\end{array}$ \\
\hline $\begin{array}{l}\text { Pyridinoline equivalents } \\
{\left[\mu \mathrm{mol} \times \mathrm{mol}^{-1} \text { creatinine] }\right.}\end{array}$ & $54.7 \pm 9.6$ & $67.4 \pm 13.1$ & $83.7 \pm 26.1^{*}$ & $40.7 \pm 9.0$ & $45.9 \pm 5.1$ \\
\hline
\end{tabular}

Median \pm SEM (standard error of arithmetic mean) is given.

Values obtained $1,3,6$ and 12 months following transplantation were compared with those obtained

1 week after transplantation.

$* \mathrm{p}<0.05$ 
Tab. 2 Comparison of bone alkaline phosphatase mass concentratións in serum and intact parathyrin values in plasma before and after renal transplantation.

\begin{tabular}{|c|c|c|c|c|c|c|}
\hline & \multirow{2}{*}{$\begin{array}{l}\text { Before } \\
\text { renal trans- } \\
\text { plantation } \\
(\mathrm{n}=20)\end{array}$} & \multicolumn{5}{|c|}{ Time after renal transplantation } \\
\hline & & $\begin{array}{l}1 \text { week } \\
(\mathrm{n}=26)\end{array}$ & $\begin{array}{l}1 \text { month } \\
(\mathrm{n}=18)\end{array}$ & $\begin{array}{l}3 \text { months } \\
(\mathrm{n}=8)\end{array}$ & $\begin{array}{l}6 \text { months } \\
(n=7)\end{array}$ & $\begin{array}{l}12 \text { months } \\
(\mathrm{n}=11)\end{array}$ \\
\hline $\begin{array}{l}\text { Bone alkaline phosphatase } \\
\text { mass concentration }[\mu \mathrm{g} / 1]\end{array}$ & $9.7 \pm 2.4$ & $4.5 \pm 1.5^{*}$ & $9.0 \pm 1.3$ & $16.0 \pm 5.3$ & $13.0 \pm 1.4$ & $13.0 \pm 1.6$ \\
\hline $\begin{array}{l}\text { Parathyrin concentration } \\
{[\mathrm{pmol} / 1]}\end{array}$ & $15.5 \pm 5.2$ & $10.5 \pm 3.0$ & $15.5 \pm 3.0$ & $9.1 \pm 2.8$ & $15.0 \pm 4.0$ & $6.4 \pm 3.1$ \\
\hline
\end{tabular}

Median \pm SEM (standard error of arithmetic mean) is given.

Values obtained after transplantation were compared with those obtained before transplantation.

$* \mathrm{p}<0.05$

Determination of $L-\gamma$-glutamyl transferase activity concentration in serum

$L-\gamma$-Glutamyl transferase activity concentration was determined according to Szász (8) using the fully mechanized analyser Hitachi/ BM 737 (Boehringer Mannheim GmbH, Mannheim, Germany) (normal range: 6-28 $\mathrm{U} / \mathrm{h}$ [males] and 4-18 $\mathrm{U} / \mathrm{\text {[females]). }}$

\section{Determination of cyclosporin $A$ in whole blood}

Cyclosporin A was determined in the supernate of deproteinized whole blood (anticoagulant: potassium salt of ethylenediaminetetraacetic acid), employing the analyser $\mathrm{TDx}^{\circledR}$ (Abbott $\mathrm{GmbH}$, Wiesbaden, Germany) and a monoclonal antibody against cyclosporin A.

\section{Statistical methods}

The statistical methods employed include the U-test according to Wilcoxon, Mann \& Whitney (two-tailed) for unpaired samples, linear regression equations, as well as linear correlation coefficients (9).

\section{Results}

Cross-sectional study of biochemical quantities before and after renal transplantation

One, 6 and 12 months after renal transplantation, urinary excretion values of pyridinium cross-links did not significantly differ from those obtained 1 week following transplantation $(p>0.05)$. There was a rise of excretion values 3 months $(p<0.001)$ after renal transplantation compared with the values obtained 1. week following transplantation.

Before transplantation the median of parathyrin concentrations was elevated, whereas that of bone alkaline phosphatase values was within the reference limits. Bone alkaline phosphatase levels decreased 1 week following renal transplantation $(p<0.01)$ but rose again 1 month after renal transplantation $(p<0.05)$. The concentrations of parathyrin following renal transplantation did not significantly differ from those before renal transplantation $(p>0.05)$ (tab. 1 and 2$)$.
Relationship between urinary excretion of pyridinium cross-links and intact parathyrin values after renal transplantation

Out of 49 sera whose corresponding plasma samples showed increased parathyrin values $(>5.8 \mathrm{pmol} / \mathrm{l}), 13$ $(27 \%)$ displayed urinary excretion values of pyridinium cross-links above the upper reference limit (pyridinoline equivalents, $93 \mu \mathrm{mol} / \mathrm{mol}$ creatinine) (tab. 3 and fig. 1).

\section{Relationship between urinary excretion of pyridinium cross-links and bone alkaline phosphatase concentrations after renal transplantation}

In the case of 17 urines with concentrations of pyridinium cross-links above the upper reference limit (pyridinoline equivalents, $93 \mu \mathrm{mol} / \mathrm{mol}$ creatinine), only 2 $(12 \%)$ of the corresponding sera showed increased bone alkaline phosphatase values $(>21.3 \mu \mathrm{g} / 1$ [males] and $>15.0 \mu \mathrm{g} / 1$ [females]). In all serum samples with bone alkaline phosphatase values exceeding the upper reference limit, the $L-\gamma$-glutamyl transferase activity concentrations were within the reference interval (tab. 4 and fig. 2).

Tab. 3 Relationship between urinary excretion of pyridinium cross-links and intact parathyrin concentrations in 70 plasma/urine samples (from 49 patients) obtained after renal transplantation.

\begin{tabular}{llll}
\hline $\begin{array}{l}\text { Number of plasma } \\
\text { samples with } \\
\text { parathyrin } \\
\text { concentrations }\end{array}$ & n & $\begin{array}{l}\text { Number of urines with pyridinium } \\
\text { cross-links excretion }\end{array}$ \\
\cline { 2 - 4 } $\begin{array}{l}\text { below the upper } \\
\text { reference limit }^{\mathrm{b}}\end{array}$ & $\begin{array}{l}\text { above the upper } \\
\text { reference limit }^{\mathrm{b}}\end{array}$ \\
\hline $\begin{array}{l}\text { below the upper } \\
\text { reference limit }\end{array}$ & 21 & $17(81 \%)$ & $4(19 \%)$ \\
$\begin{array}{l}\text { above the upper } \\
\text { reference limit }\end{array}$ & 49 & $36(73 \%)$ & $13(27 \%)$
\end{tabular}

a $5.8 \mathrm{pmol} / 1$

b pyridinoline equivalents, $93 \mu \mathrm{mol} / \mathrm{mol}$ creatinine 


\section{Relationship between bone alkaline} phosphatase concentrations and intact parathyrin values after renal transplantation

Out of 49 sera whose corresponding plasma samples showed increased parathyrin values $(>5.8 \mathrm{pmol} / \mathrm{l}), 8$ (18\%) displayed bone alkaline phosphatase concentration above the upper reference limit $(21.3 \mu \mathrm{g} / \mathrm{l}$ [males] and $15.0 \mu \mathrm{g} / \mathrm{l}$ [females]) (fig. 3).

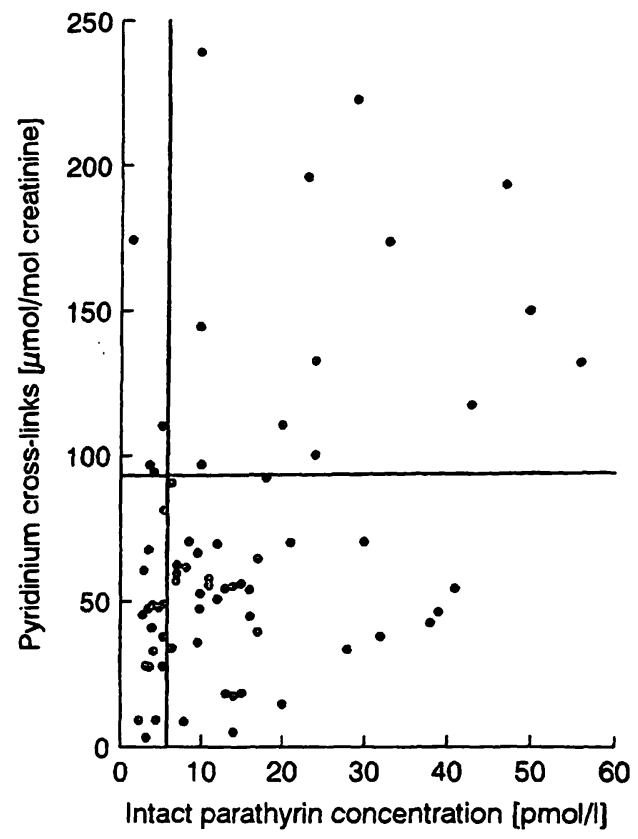

Fig. 1 Relationship between urinary excretion of pyridinium cross-links and intact parathyrin concentrations in 70 plasma/urine samples from 49 patients following renal transplantation.

The horizontal line indicates the upper reference limit (97.5th percentile) of pyridinium cross-links excretion (pyridoline equivalents, $93 \mu \mathrm{mol} / \mathrm{mol}$ creatinine). The vertical line denotes the upper reference limit (97.5th percentile) of parathyrin concentration (5.8 $\mathrm{pmol} / \mathrm{l})$.

Tab. 4 Relationship between urinary excretion of pyridinium cross-links and bone alkaline phosphatase mass concentrations in 70 serum/urine samples (from 49 patients) obtained after renal transplantation.

\begin{tabular}{|c|c|c|c|}
\hline \multirow{2}{*}{$\begin{array}{l}\text { Number of sera } \\
\text { with bone alkaline } \\
\text { phosphatase } \\
\text { concentrations }\end{array}$} & \multirow[t]{2}{*}{$\mathrm{n}$} & \multicolumn{2}{|c|}{$\begin{array}{l}\text { Number of urines with pyridinium } \\
\text { cross-links excretion }\end{array}$} \\
\hline & & $\begin{array}{l}\text { below the upper } \\
\text { reference limit }\end{array}$ & $\begin{array}{l}\text { above the upper } \\
\text { reference limit }\end{array}$ \\
\hline $\begin{array}{l}\text { below the upper } \\
\text { reference limit }\end{array}$ & 62 & $47(76 \%)$ & $15(24 \%)$ \\
\hline $\begin{array}{l}\text { above the upper } \\
\text { reference limit }\end{array}$ & 8 & $6(75 \%)$ & $2(25 \%)$ \\
\hline
\end{tabular}

\footnotetext{
a $21.3 \mu \mathrm{g} / \mathrm{l}$ [males] and $15.0 \mu \mathrm{g} / 1$ [females], respectively

b pyridinoline equivalents, $93 \mu \mathrm{mol} / \mathrm{mol}$ creatinine
}

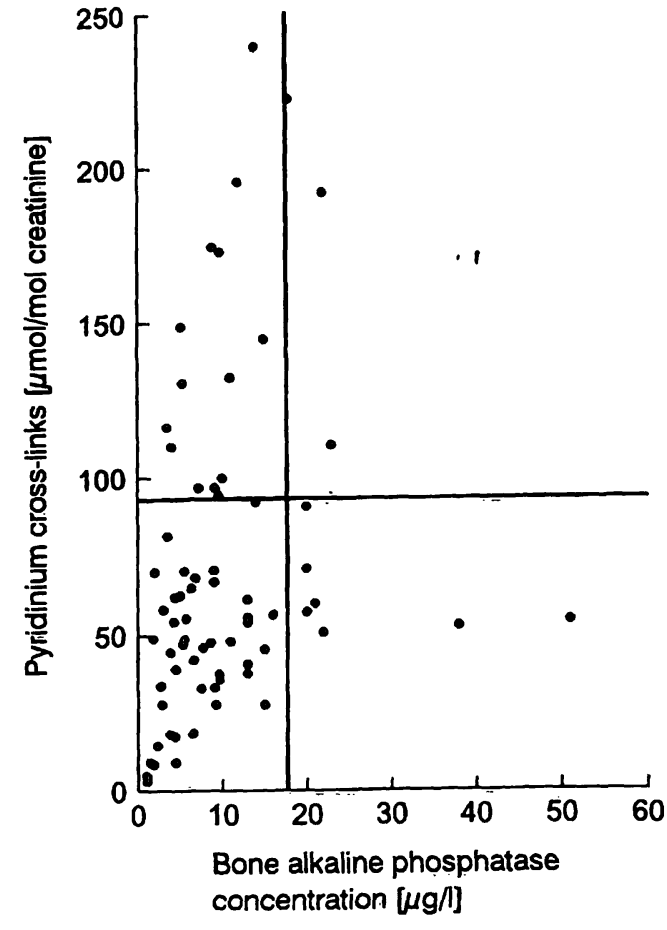

Fig. 2 Comparison between urinary excretion of pyridinium cross-links and bone alkaline phosphatase mass concentrations in 70 serum/urine samples from 49 patients following renal transplantation.

The horizontal and vertical lines indicate the upper reference limits (97.5th percentile) of pyridinium cross-links excretion (pyridinoline equivalents, $93 \mu \mathrm{mol} / \mathrm{mol}$ creatinine) and bone alkaline phosphatase $(17.7 \mu \mathrm{g} / \mathrm{l})$ without taking into consideration the dependence of bone alkaline phosphatase reference values on sex.

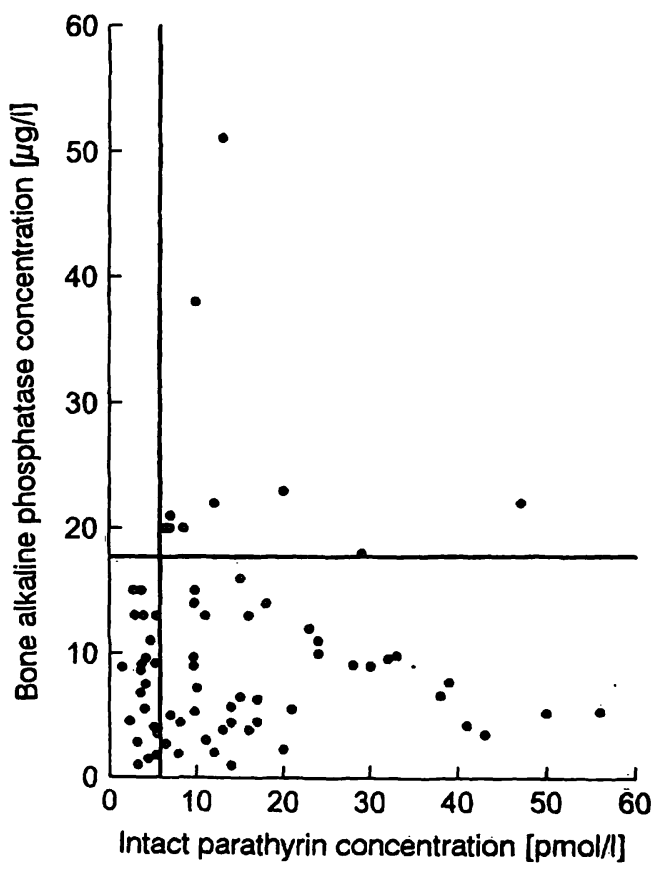

Fig. 3 Relationship between bone alkaline phosphatase mass concentrations and intact parathyrin values in 70 serum/plasma samples from 49 patients following renal transplantation.

The horizontal line indicates the upper reference limit $(97.5$ th percentile) of bone alkaline phosphatase $(17.7 \mu \mathrm{g} / \mathrm{l})$ without taking into consideration the dependence of bone alkaline phosphatase reference values on sex. The vertical line denotes the upper reference limit (97.5th percentile) of parathyrin concentration (5.8 $\mathrm{pmol} / \mathrm{l})$. 


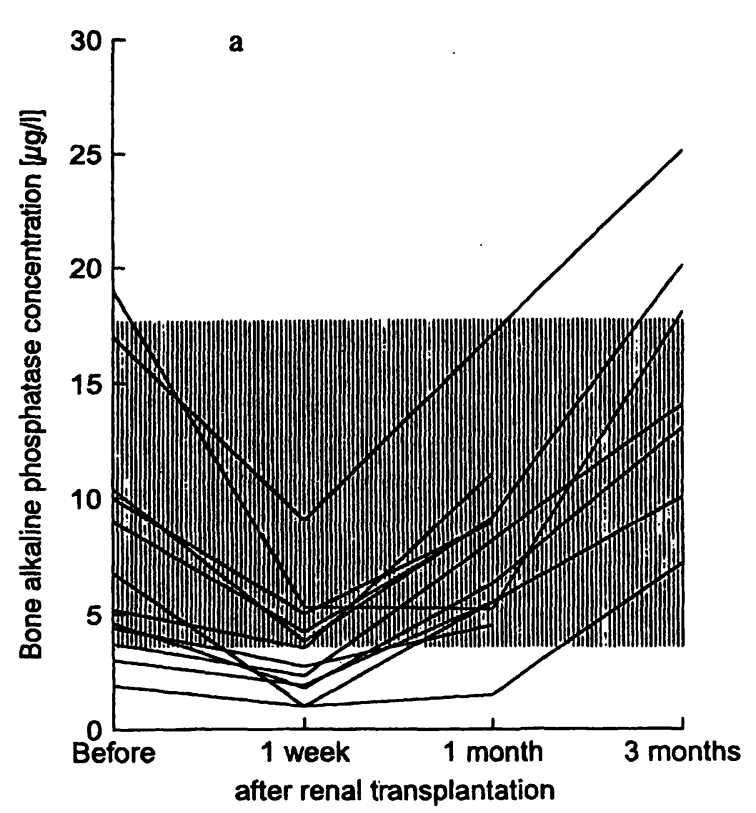

Fig. 4 Follow-up of bone alkaline phosphatase concentrations (fig. 4a) and pyridinium cross-links excretion values (fig. 4b) in 12 patients showing bone alkaline phosphatase concentrations within or below the reference interval before renal transplantation. The shaded areas denote the reference limits of bone alkaline phos-

Follow-up of the excretion of pyridinium cross-links and the concentration of bone alkaline phosphatase after renal transplantation

The plasma concentration of bone alkaline phosphatase and the urinary excretion of pyridinium cross-links were monitored in 12 patients who showed a bone alkaline phosphatase concentration within (10 cases) or below the reference interval ( 2 cases).

There was a decrease of bone alkaline phosphatase 1 week after renal transplantation $(p<0.01)$ compared with the corresponding concentrations before transplantation. Bone alkaline phosphatase concentrations increased again 1 month following transplantation $(p<0.05)$. Three months after transplantation, bone alkaline phosphatase mass concentrations were higher than before transplantation $(p<0.05)$. There was a rise in the urinary excretion of pyridinium cross-links 1 and 3 months after transplantation, compared with the corresponding values 1 week following transplantation $(p<0.05)$. Excretion levels of cross-links and mass concentrations of bone alkaline phosphatase were correlated at all times following transplantation $(p<0.001)$ (tab. 5 and fig. 4).

\section{Discussion}

Persistence of high intact parathyrin concentrations following renal transplantation is due to a hypersecretion of this hormone by hyperplastic parathyroid glands (10).

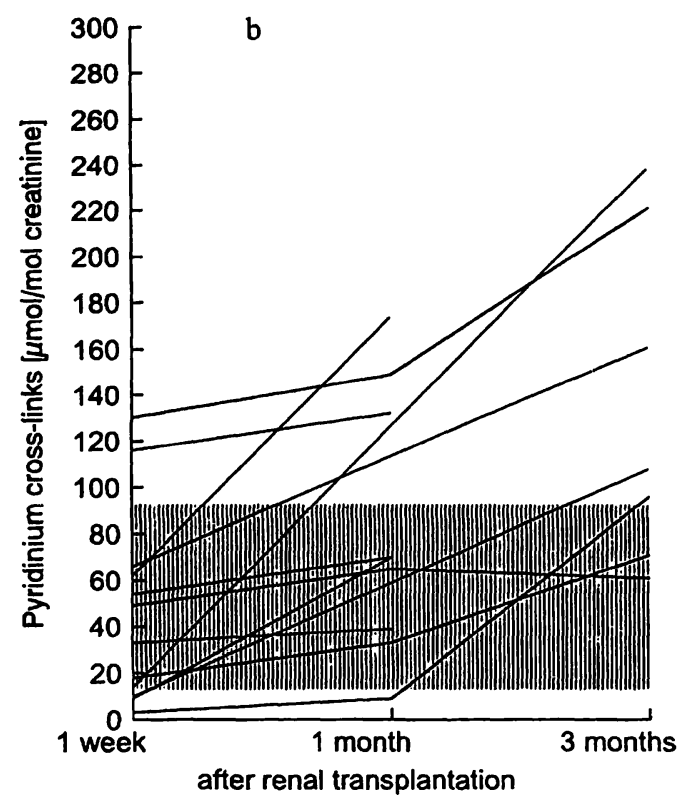

phatase concentrations $(3.6-17.7 \mu \mathrm{g} / \mathrm{l})$ and of pyridinium crosslinks excretion $(13-93 \mu \mathrm{mol} / \mathrm{mol}$ creatinine) without taking into consideration the dependence of bone alkaline phosphatase values upon sex.

A follow-up revealed a rise of bone alkaline phosphatase concentrations 3 months after renal transplantation. In view of the lack of correlation between intact parathyrin and bone alkaline phosphatase concentrations, it seems unlikely that parathyrin action on bone tissue is responsible for this increase.

Several groups have observed an increase of bone alkaline phosphatase following renal transplantation $(11,12)$ which is most probably due to an activation of osteoblasts by cyclosporin A (13):

Tab. 5 Correlation coefficients between urinary excretion of pyridinium cross-links, concentrations of bone alkaline phosphatase, intact parathyrin values and serum creatinine levels in 28 serum/ plasma/urine samples from 12 patients after renal transplantation.

\begin{tabular}{lll}
\hline Analytes & $\begin{array}{l}\text { Correlation } \\
\text { coefficients }\end{array}$ & Significance \\
\hline
\end{tabular}

\begin{tabular}{llc}
\hline $\begin{array}{l}\text { Pyridinium cross-links } \\
\text { vs bone alkaline phosphatase }\end{array}$ & $\mathrm{r}=+0.634$ & $\mathrm{p}<0.001$ \\
$\begin{array}{l}\text { Pyridinium cross-links } \\
\text { vs intact parathyrin }\end{array}$ & $\mathrm{r}=+0.278$ & $\mathrm{p}>0.05$ \\
$\begin{array}{l}\text { Bone alkaline phosphatase } \\
\text { vs intact parathyrin }\end{array}$ & $\mathrm{r}=-0.051$ & $\mathrm{p}>0.05$ \\
$\begin{array}{l}\text { Pyridinium cross-links } \\
\text { vs creatinine }\end{array}$ & $\mathrm{r}=+0.182$ & $\mathrm{p}>0.05$ \\
$\begin{array}{l}\text { Bone alkaline phosphatase } \\
\text { vs creatinine }\end{array}$ & $\mathrm{r}=-0.194$ & $\mathrm{p}>0.05$ \\
$\begin{array}{l}\text { Intact parathyrin } \\
\text { vs creatinine }\end{array}$ & $\mathrm{r}=+0.194$ & $\mathrm{p}>0.05$ \\
\hline
\end{tabular}


(a) thirteen of 17 patients with normal alkaline phosphiatase activities before renal transplantation who were treated with cyclosporin A showed increased alkaline phosphatase values one year after renal transplantation compared with only 1 of 12 patients receiving azathioprine/prednisolone (14);

(b) reduction of the cyclosporin A dosage results in reduced bone alkaline phosphatase values (4);

(c) histomorphometric data show that osteoblast activity is increased in patients following renal transplantation who have received cyclosporin $\mathrm{A}$ as an immunosuppressive agent (14);

(d) in rats cyclosporin A produced high bone remodelling, with bone resorption exceeding bone formation, when daily cyclosporin A oral doses of $15 \mathrm{mg} / \mathrm{kg}$ body weight were administered (15).

The urinary excretion of pyridinium cross-links was increased 1 and 3 months after renal transplantation. This may be due either to high bone remodelling induced by cyclosporin A (15) or to an enhancement of bone resorption caused by glucocorticoids (16).

Glucocorticoids cause bone loss by diminishing the conversion of precursor cells to functioning osteoblasts and by decreasing the synthesis of collagen (5). A decrease of bone alkaline phosphatase values within the first week following renal transplantation can be explained by the high doses of corticosteroids given in this period (17).

\section{References}

1. Risteli J, Elomaa I, Niemi S, Novamo A, Risteli L. Radioimmunoassay for the pyridinoline cross-linked carboxy-terminal telopeptide of type I collagen: a new marker of bone collagen degradation. Clin Chem 1993; 39:635-40.

2. Seibel MJ. Hydroxy-Pyridinium "Crosslinks" im Urin als spezifischer Marker der Knochenresorption bei metabolischen Knochenerkrankungen. Klin Lab 1992; 38:642-3.

3. Seibel MJ, Gartenberg F, Silverberg SJ, Ratcliffe A, Robins SP, Bilezikian JP. Urinary hydroxypyridinium cross-links of collagen in primary hyperparathyroidism. J Clin Endocrinol Metab 1992; 74:481-6.

4. Van Straalen JP, Sanders E, Prummel MF, Sanders GTB. Bone alkaline phosphatase as indicator of bone formation. Clin Chim Acta 1991; 201:27-34.

5. Julian BA, Quarles LD, Niemann KMW. Musculoskeletal complications after renal transplantation: pathogenesis and treatment. Am J Kidney Dis 1992; 19:99-120.

6. Withold W, Degenhardt S, Heins M, Grabensee B, Reinauer $\mathrm{H}$. Monitoring of bone resorption by urinary excretion of pyridinium cross-links in patients receiving renal transplants ( $\mathrm{Ab}$ stract). Clin Chem 1994; 40:1134-5.

7. Helger $R$, Rindfrey $H$, Hilgenfeldt $J$. Eine Methode zur direkten Bestimmung des Creatinins im Serum und Urin ohne Enteiweißung nach einer modifizierten Jaffé-Methode. Z Klin Chem Klin Biochem 1974; 12:344-9.
There was a correlation between the serum mass concentrations of bone alkaline phosphatase and the urinary concentrations of pyridinium cross-links following renal transplantation. This is in concordance with findings in patients with primary hyperparathyroidism (3) or bone metastases (18), in which osteoblastic and osteoclastic activity are usually coupled.

For the interpretation of bone alkaline phosphatase values (as determined immunoradiometrically) it has to be taken into account that the antibodies employed in the test show $16 \%$ cross reactivity with liver alkaline phosphatase $(19,20)$. In the sera examined in the present study interference by liver alkaline phosphatase can be excluded since all sera with increased bone alkaline phosphatase mass concentrations showed $L-\gamma$-glutamyl transferase activity concentrations within the reference range.

It is worth mentioning that only $2(12 \%)$ out of 17 urines with excretion values of pyridinium cross-links above the upper reference limit were characterized by increased bone alkaline phosphatase values. In patients following renal transplantation simultaneous assessment of bone formation and bone resorption (determined from bone alkaline phosphatase serum concentrations and the excretion of pyridinium cross-links) may therefore enhance the diagnostic sensitivity for detecting effects on bone metabolism.

\section{Acknowledgement}

We thank Miss $R$. Brand for skilful technical help.

8. Szasz G. $\gamma$-Glutamyl-Transpeptidase. In: Bergmeyer HU, editor. Methoden der enzymatischen Analyse. Weinheim: Verlag Chemie, 1974:757-62.

9. Sachs L. Statistische Methoden, Planung und Auswertung. 6th ed. Heidelberg: Springer, 1988.

10. Alsina J, Gonzalez MT, Bonnin R, Ricart Y, Castelo AM, Gonzalez C, Grino JM. Long-term evolution of renal osteodystrophy after renal transplantation. Transplant Proc 1989; 21:2151-8.

11. Loertscher R, Thiel G, Harder F, Brunner FP. Persistent elevation of alkaline phosphatase in cyclosporine-treated renal transplant recipients. Transplantation $1983 ; 36: 115-6$.

12. Schmidt H, Stracke H, Schatz H, Scheuermann EH, Fassbinder W, Schoeppe W. Osteocalcin serum levels in patients following renal transplantation. Klin Wochenschr 1989; 67:297-303.

13. Withold W, Degenhardt S, Castelli D, Heins M, Grabensee B. Monitoring of osteoblast activity with an immunoradiometric assay for determination of bone alkaline phosphatase mass concentration in patients receiving renal transplants. Clin Chim Acta 1994; 225:137-146.

14. Wilmink JM, Bras J, Surachno S, van Heyst JLAM, van der Horst JM. Bone repair in cyclosporin treated renal transplant patients. Transplant Proc 1989; 21:1492-4. 
15. Stein B, Takizawa $M$, Schlosberg M, Movsowitz C, Fallon $M$, Berlin JA, Epstein S. Evidence that cyclosporine $G$ is less deleterious to rat bone in vivo than cyclosporine $A$. Transplantation 1992; 53:628-32.

16. Kelly PJ, Atkinson K, Ward RL, Sambrook PN, Biggs JC, Eisman JA. Reduced bone mineral density in men and women with allogeneic bone marrow transplantation. Transplantation 1990; 50:881-2.

17. Cundy T, Kanis JA. Rapid suppression of plasma alkaline phosphatase activity after renal transplantation in patients with osteodystrophy. Clin Chim Acta 1987; 164:285-291.

18. Paterson CR, Robins SP, Horobin JM, Preece PE, Cuschieri A. Pyridinium crosslinks as markers of bone resorption in patients with breast cancer. Br J Cancer 1991; 64:884-6.

19. Garnero P, Delmas PD. Assessment of the serum levels of bone alkaline phosphatase with a new immunoradiometric assay in patients with metabolic bone disease. J Clin Endocrinol Metab 1993; 77:1046-53.

20. Withold W, Rick W. Evaluation of an immunoradiometric assay for determination of bone alkaline phosphatase mass concentration in human sera. Eur $\mathrm{J}$ Clin Chem Clin Biochem 1994; 32:91-5.

Dr. med. Wolfgang Withold

Institut für Klinische Chemie und Laboratoriumsdiagnostik

Medizinische Einrichtungen der

Heinrich-Heine-Universität Düsseldorf

Moorenstraße 5

D-40225 Düsseldorf

Germany 
